\title{
Pengaruh Model Pembelajaran Make A Match dengan Berbantuan Media Kartu Berpasangan Terhadap Hasil Belajar Matematika
}

\author{
Ni Komang Ida Riana1*, I Made Tegeh², Ketut Pudjawan ${ }^{3}$ \\ ${ }^{123}$ Program Studi Pendidikan Guru Sekolah Dasar, Universitas Pendidikan Ganesha
}

\begin{abstract}
Abstrak
Penelitian ini bertujuan untuk mendeskripsikam hasil belajar matematika siswa yang dibelajarkan dengan model pembelajaran Make A Match berbantuan media kartu berpasangan dan yang tidak dibelajarkan dengan model pembelajaran Make A Match berbantuan media kartu berpasangan, serta mengetahui perbedaan hasil belajar matematika antara siswa yang dibelajarkan dengan model pembelajaran Make A Match berbantuan media kartu berpasangan dan siswa yang dibelajarkan dengan bukan model pembelajaran Make A Match berbantuan media kartu berpasangan pada siswa kelas III. Jenis penelitian ini adalah eksperimen semu atau Quasi Experiment. Populasi dalam penelitian ini adalah seluruh siswa kelas yang berjumlah 92 orang. Sampel dalam penelitian berjumlah 47 orang siswa. Penentuan sampel penelitian dengan menggunakan cluster random sampling. Data hasil belajar matematika siswa dikumpulkan dengan instrumen tes berbentuk pilihan ganda. Data yang dikumpulkan dianalisis menggunakan analisis statistik deskriptif dan statistik inferensial (uji-t). berdasarkan hasil analisis data, diperoleh hasil yaitu: (1) rata-rata hitung hasil belajar siswa kelompok eksperimen berada pada kategori sangat tinggi, (2) rata-rata hitung hasil belajar siswa kelompok kontrol berda pada kategori tinggi, serta (3) hasil uji-t yang menunjukkan bahwa $t_{h i t}>t_{t a b}$, sehingga dapat disimpulkan bahwa terdapat perbedaan yang signifikan hasil belajar matematika antara siswa yang dibelajarkan dengan model pembelajaran Make A Match berbantuan media kartu berpasangan dan siswa yang dibelajarkan dengan bukan model pembelajaran Make A Match berbantuan media kartu berpasangan
\end{abstract}

\begin{abstract}
This study aims to describe students' mathematics learning outcomes that are learned with the Make A Match learning model aided by paired card media and those that are not taught with the Make A Match learning model aided by the paired card media, and to know the differences in mathematics learning outcomes between students who are taught with the learning model Make A Match is assisted by a pair of card media and students who are taught by not learning models Make A Match are assisted by a paired card media to class III students. This type of research is quasiexperimental or Quasi Experiment. The population in this study were all 92 class students. The sample in this study amounted to 47 students. Determination of the research sample using cluster random sampling. Student mathematics learning outcomes data were collected with a multiple choice test instrument. Data collected were analyzed using descriptive statistical analysis and inferential statistics (t-test). based on the results of data analysis, the results obtained are: (1) the average student learning outcomes in the experimental group are in the very high category, (2) the average student learning outcomes in the control group are high, and (3) the test results - $t$ which shows that thit> ttab, so it can be concluded that there is a significant difference in mathematics learning outcomes between students who are taught with the Make A Match learning model assisted by paired card media and students who are taught with nonlearning models. Make A Match is assisted by paired card media.
\end{abstract}

\footnotetext{
* Corresponding author. 


\section{PENDAHULUAN}

Kita sebagai manusia yang memiliki akal dan pikiran tentu sadar akan arti pentingnya pendidikan bagi generasi masa depan. Gandhi (2011:61) menyatakan bahwa, "pendidikan sebagai kata benda berarti proses perubahan sikap dan tingkah laku seseorang atau kelompok dalam usaha mendewasakan manusia melalui upaya pengajaran dan latihan". Susanty dkk., (2014) menyatakan bahwa, "pendidikan sangat penting bagi kehidupan umat manusia. Pendidikan merupakan upaya yang sangat luhur dalam meningkatkan kualitas manusia, sehingga segala usaha yang mengarah pada keberhasilan pendidikan merupakan sebuah keharusan". Selain itu, Pertiwi dkk., (2019) juga menyatakan bahwa, "pendidikan merupakan salah satu usaha manusia untuk membina kepribadiannya sesuai dengan nilai-nilai di dalam masyarakat dan kebudayaan.". Oleh karena itu, pendidikan di Indonesia selalu diperbarui sesuai dengan perkembangan zaman agar sesuai dengan kemajuan dari pertama kali diterapkan sampai saat ini.

Salah satu bukti nyata adalah perubahan kurikulum. Yulianti \& Yuliasih (2016:12) menjelaskan bahwa, "secara lebih luas kurikulum dapat diartikan semua kegiatan dan pengalaman belajar serta segala sesuatu yang berpengaruh terhadap pembentukan pribadi peserta didik atas tanggung jawab sekolah untuk mencapai tujuan pendidikan". Perubahan kurikulum ini terjadi sebagai bahan untuk penyempurnaan kurikulum sebelumnya sehingga terbentuklah Kurikulum baru yang sesuai dengan perkembangan zaman. Tentu saja perubahan ini diiringi dengan harapan-harapan yang bersifat positif seperti peserta didik lebih aktif dalam kegiatan pembelajaran, proses pembelajaran yang lebih baik dan nyaman, dan harapan agar adanya perubahan ini mampu terciptanya kualitas pendidikan yang lebih unggul di negara Indonesia. Namun, sebagai umat yang tidak sempurna pendidik dan peserta didik tentu perlu melakukan pembiasaan, pencocokan, atau penyesuaian dalam menerapkan kurikulum tersebut dalam proses pembelajaran sehingga timbullah kendala-kendala yang ada dalam penerapan Kurikulum 2013 tersebut di sekolah-sekolah yang tidak sesuai dengan harapan-harapan yang ada.

Tentu perubahan kurikulum ini terjadi di semua jenjang, tanpa terkecuali jenjang Sekolah Dasar (SD). Karena perubahan ini, tentu proses pembelajaran juga berubah dalam setiap mata pelajaran, mengingat sekarang sudah menjadi pembelajaran terpadu. Suranata dkk., (2018) menyatakan bahwa, "pembelajaran merupakan komunikasi dua arah, mengajar dilakukan oleh pihak guru sebagai pendidik, sedangkan belajar dilakukan oleh peserta didik". Salah satu pembelajaran tematik yang diajarkan di kelas III adalah matematika. Matematika merupakan salah satu mata pelajaran yang mengajarkan peserta didik yang lebih banyak pada perhitungan. Parjayanti dan Wardono (dalam Tarigan, 2014) menyatakan bahwa, "banyak siswa yang beranggapan bahwa matematika merupakan mata pelajaran yang sulit karena mempelajari ide-ide atau konsep yang bersifat abstrak. Dalam hal ini terlihat siswa tidak termotivasi untuk aktif saat mengikuti pembelajaran matematika di kelas". Hudojo (dalam Harsa, 2017) menyatakan bahwa "pembelajaran matematika merupakan suatu upaya/kegiatan (merancang dan menyediakan sumber-sumber belajar, membantu/membimbing, memotivasi, mengarahkan) dalam membelajarkan siswa untuk mencapai tujuan pembelajaran matematika".

Pelajaran Matematika dalam proses pembelajaran di sekolah diharapkan bukanlah menjadi mata pelajaran yang ditakuti, mengingat mata pelajaran ini sering menjadi momok bagi sebagain besar siswa karena dari awal siswa sudah menanam konsep bahwa matematika adalah mata pelajaran yang menakutkan. Dengan mengenal Matematika lebih dalam lagi diharapkan agar siswa mampu menerima materi pembelajaran dengan antusias dan semangat yang diberikan oleh guru, dan dapat meningkatkan hasil belajar siswa yang maksimal baik mengenai konsep-konsep materi maupun hitung angka yang beragam mulai dari penjumlahan, pengurangan, perkalian, dan pembagian. Dengan demikian, siswa dapat mengikuti kegiatan pembelajaran dengan baik dan memiliki hasil belajar yang baik pula. Andri dkk., (2016) menyatakan bahwa, "hasil belajar adalah kemampuan- kemampuan yang dimiliki siswa setelah ia menerima pengalaman belajarnya". Hutauruk \& Simbolon (2018) menyatakan bahwa, "hasil belajar adalah pencapaian bentuk perubahan perilaku yang cenderung menetap dari ranah kognitif, afektif, dan psikomotorik dari proses belajar yang dilakukan dalam waktu tertentu". Hasil belajar merupakan perubahan perilaku baik peningkatan pengetahuan, perbaikan sikap, maupun peningkatan keterampilan yang dialami siswa setelah menyelesaikan kegiatan pembelajaran (Pratiwi, 2015). Djamarah (dalam Sutrisno, 2018) menyatakan bahwa, "hasil belajar adalah prestasi dari suatu kegiatan yang telah dikerjakan, diciptakan, baik secara individu maupun tim". Sejalan dengan itu, Abadi dkk., (2018) juga menyatakan bahwa, "hasil belajar adalah kemampuan yang diperoleh dari kegiatan belajar".

Berdasarkan hasil observasi dan wawancara yang dilakukan oleh penulis, terdapat banyak kendalakendala yang dihadapi oleh guru dan peserta didik dalam proses pembelajaran matematika. Kendala yang ada adalah pendidik hanya perlu melakukan penyesuaian yang lebih mendalam agar mampu menerapkan kurikulum dengan baik. Selain itu kendala yang dihadapi adalah kesabaran pendidik dalam menghadapi peserta didik yang sulit diatur. Sedangkan dari pihak peserta didik, berdasarkan hasil wawancara dengan 
wali kelas lebih banyak lagi kendala yang dihadapi. Kendala-kendala tersebut antara lain 1) peserta didik ada yang masih kesulitan membaca, 2) peserta didik sulit diatur atau harus diberitahu berkali-kali, 3) peserta didik harus dipuji agar lebih semangat dalam belajar, 4) peserta didik sering memberikan keluhan atau laporan-laporan atas kejadian yang dialami di sekolah yang dilakukan oleh teman mereka, 5) pengajaran sebatas alat peraga yang ada di kelas tersebut, 6) karena memakai kurikulum 2013, perlu penyesuaian dalam kapasitas otak anak, yang dimaksudkan disini adalah terdapat anak yang sangat aktif, aktif, dan kurang aktif, 7) terdapat anak yang pandai dalam hitung-hitungan, tidak terlalu menonjol dalam hitung-hitungan, bahkan sulit dalam hitung-hitungan. Selain melakukan observasi dan wawancara, penulis juga melakukan pencatatan dokumen. Pencatatan dokumen ini adalah mengenai hasil Penilaian Tengah Semester (PTS) pada mata pelajaran Matematika siswa kelas III di Gugus I Melinggih, Kecamatan Payangan, Kabupaten Gianyar.

Berdasarkan pencatatan dokumen, nilai rata-rata ulangan tengah semester untuk mata pelajaran matematika kelas III belum optimal karena masih ada siswa yang nilainya kurang dari KKM yang sudah ditetapkan di setiap satuan pendidikan. Berdasarkan permasalahan yang terdapat pada kelas tersebut, salah satu upaya yang dapat dilakukan untuk mengatasi permasalahan tersebut di atas adalah penerapan model Make A Match. Penulis menggunakan model pembelajaran ini karena dari hasil analisis permasalahan yang didapat pada kelas III tersebut, model ini sangat cocok diterapkan mengingat terjadi kendala dalam penerapan Kurikulum 2013 dan mengacu pada masalah yang dialami oleh peserta didik mengenai pembelajaran pada kelas III tersebut. Hal ini didasarkan pada karakteristik siswa yang cenderung ingin belajar sambil bermain. Nurdyansah \& Fahyuni (2016:77) menyatakan, model Make A Match (membuat pasangan) merupakan salah satu jenis dari model dalam pembelajaran kooperatif. Model ini dikembangkan oleh Lorna Curran (1994). Salah satu keuntungan dari model ini adalah siswa mencari pasangan sambil belajar mengenai suatu konsep atau topik, dalam suasana yang menyenangkan. Penerapan model ini dimulai dengan teknik, yaitu siswa disuruh mencari pasangan kartu yang merupakan jawaban atau soal sebelum batas waktunya, siswa yang dapat mencocokkan kartunya akan diberi poin. Lie (dalam Zahroul \& Nur, 2014) menyatakan bahwa, "Make A Match adalah suatu teknik pembelajaran dalam model pembelajaran kooperatif yang menggunakan kartu sebagai media pembelajaran untuk berinteraksi dengan kelompoknya (pasangannya) agar pembelajaran menjadi menarik dan menyenangkan". Selain itu, Elin Rosalin (dalam Arifiyanti, 2016) menyatakan bahwa, "Model pembelajaran Make A Match adalah model pembelajaran dimana guru menyiapkan kartu yang berisi persoalanpermasalahan dan kartu yang berisi jawaban". Model pembelajaran Make A Match adalah metode pembelajaran kelompok yang memiliki dua orang anggota. Masing-masing anggota kelompok tidak diketahui sebelumnya tetapi dicari berdasarkan kesamaan pasangan misalnya pasangan soal dan jawaban (Mulyatiningsih, 2011).

Dengan menerapkan model ini tentu saja akan meningkatkan keaktifan peserta didik dalam proses pembelajaran mengingat karakteristik peserta didik yang lebih banyak ingin bermain. Sehingga model pembelajaran ini mengajak peserta didik untuk belajar sambil bermain. Hal-hal positif yang didapat dari model pembelajaran ini adalah meningkatkan motivasi peserta didik dalam belajar karena peserta didik dalam keadaan senang mengikuti kegiatan belajar sambil bermain. Hal inilah yang meningkatkan semangat sehingga peserta didik diharapkan mampu lebih aktif dalam kegiatan belajar dan dengan model ini peserta didik mampu meningkatkan hasil belajar matematikanya. Untuk meningkatkan nilai hasil belajar tersebut, tentu perlunya ada bantuan seperti media atau alat pembelajaran untuk menunjang penerapan model pembelajaran tersebut.

Adapun hasil penelitian yang relevan dengan model pembelajaran yang dilakukan dalam penelitian ini adalah penelitian yang dilakukan oleh Dari (2016) dengan skripsi berjudul Pengaruh Pendekatan Konvensional Berbasis Model Pembelajaran Kooperatif Tipe Make A Match Terhadap Kompetensi Pengetahuan PKn Siswa Kelas V SD Gugus Letkol Wisnu Tahun Pelajaran 2015/2016. Hasil dari penelitian tersebut adalah terdapat perbedaan yang signifikan kompetensi pengetahuan PKn antara siswa yang dibelajarkan dengan pendekatan konvensional berbasis model pembelajaran kooperatif tipe Make $A$ Match dan siswa yang dibelajarkan dengan pendekatan konvensional pada siswa kelas V SD Gugus Letkol Wisnu Tahun Pelajaran 2015/2016. Penelitian yang dilakukan oleh Dewi (2017) dengan skripsi berjudul Pengaruh Model Pembelajaran Make A Match Berbatuan Media Konkrit Terhadap Hasil Belajar IPA Siswa Kelas V SD Gugus III Kecamatan Jembrana Kabupaten Jembrana Tahun Pelajaran 2016/2017. Hasil dari penelitian tersebut adalah pembelajaran dengan model pembelajaran Make A Match berbantuan media konkrit berpengaruh positif terhadap hasil belajar IPA siswa SD Kelas V di Gugus III Kecamatan Jembrana Kabupaten Jembrana Tahun Pelajaran 2016/2017. Penelitian yang dilakukan oleh Tiballa (2017) dengan skripsi berjudul Pengaruh Model Pembelajaran Kooperatif Tipe Make A Match Berbatuan Peta Pikiran Terhadap Hasil Belajar IPA Siswa Kelas V Sekolah Dasar Gugus X Kecamatan Buleleng Kabupaten Buleleng Tahun Pelajaran 2016/2017. Hasil dari penelitian tersebut adalah terdapat perbedaan hasil belajar IPA antara siswa kelas $\mathrm{V}$ yang mendapat perlakuan model pembelajaran kooperatif tipe Make A Match 
berbatuan peta pikiran dan siswa kelas $\mathrm{V}$ yang tidak mendapat perlakuan model pembelajaran kooperatif tipe Make A Match berbatuan peta pikiran di Gugus X Kecamatan Buleleng Kabupaten Buleleng Tahun Pelajaran 2016/2017.

Berdasarkan pengertian dari model pembelajaran Make A Match, akan lebih efektif lagi dengan berbantuan media Kartu Berpasangan. Rifai (2010:1.5) menyatakan bahwa, kata media merupakan bentuk jamak dari kata medium, dimana kata tersebut berasal dari kata Latin yang secara harfiah memiliki arti perantara atau pengantar. Media merupakan perantara atau pengantar dari pengirim, ke penerima pesan. Purniawati (dalam Novayanti, 2017) menyatakan bahwa, "media card match merupakan media kartu berpasangan antara satu kartu dengan kartu yang lainya. Media ini digunakan untuk meningkatkan kemampuan kognitif anak usia dini. Kartu pasangan adalah suatu media yang berbentuk seperti kartu yang biasanya dibuat dari bahan kertas yang saling memiliki pasangan". Nugraha, dkk., (2013) menyatakan bahwa, "media pendidikan dengan bentuk kartu berpasangan menjadikan kelas jauh dari ketegangan sehingga memudahkan siswa menerima pelajaran dan diharapkan siswa lebih mudah mempelajari dan memahami isi materi dan mampu meningkatkan daya keaktifan siswa dalam belajar serta dapat mengembangkan pengetahuan, sikap dan ketrampilan sehingga dapat berkembang secara mandiri".

Mengenai media Kartu Berpasangan ini, sesuai dengan namanya, media ini menggunakan 2 jenis kartu. Pada jenis kartu yang pertama merupakan kartu pertanyaan dan jenis kartu yang kedua adalah kartu jawaban. Pada masing-masing kartu tersebut, sudah berisi pertanyaan-pertanyaan dan jawabanjawaban yang cocok sesuai dengan jenis dari kartu tersebut. Pada saat pembelajaran menggunakan media ini, peserta didik akan dibagi menjadi 2 kelompok yaitu kelompok pertanyaan dan kelompok jawaban. Setelah mengambil jenis kartu yang berisi pertanyaan atau jawaban, tiap-tiap siswa harus mencari pasangannya yang sesuai dengan pertanyaan dan jawaban yang dipegang oleh siswa tersebut. Setelah menemukan pasangan yang cocok, peserta didik akan menempelkan pertanyaan dan jawaban tersebut di papan tulis agar semua siswa mengetahui apa soal dan jawaban dari kartu yang dipegang oleh masingmasing siswa. Kemudian akan dilanjutkan dengan siswa yang lainnya secara bergantian.

Model dan media tersebut akan diterapkan pada pembelajaran tematik khususnya pada kelas III. Haji (2015) menyatakan bahwa, "pembelajaran tematik adalah pembelajaran yang dirancang berdasarkan tema-tema tertentu, dalam pengertian lain, pembelajaran tematik adalah pembelajaran terpadu yang menggunakan tema untuk mengaitkan beberapa mata pelajaran sehingga dapat memberikan pengalaman bermakna pada peserta didik". Dengan demikian, pendidik haruslah mampu mengaitkan antara pelajaran yang satu dengan mata pelajaran yang lain yang terdapat dalam suatu tema agar menjadi sebuah pembelajaran yang terpadu yang sesuai dengan pengertian pembelajaran tematik itu sendiri. Dengan penerapan model Make A Match berbantuan media kartu berpasangan ini bertujuan untuk mengetahui apakah terdapat pengaruh dari model tersebut terhadap hasil belajar matematika siswa kelas III.

Berdasarkan uraian di atas, model pembelajaran Make A Match sangat efektif untuk meningkatkan hasil belajar matematika siswa. Oleh karena itu judul penelitian ini adalah "Pengaruh Model Pembelajaran Make A Match dengan Berbantuan Media Kartu Berpasangan Terhadap Hasil Belajar Matematika Kelas III Gugus I Melinggih Kecamatan Payangan Kabupaten Gianyar Tahun Pelajaran 2019/2020".

\section{METODE PENELITIAN}

Penelitian ini dilaksanakan di kelas III pada semester II di Gugus I Melinggih, Kecamatan Payangan, Kabupaten Gianyar tahun pelajaran 2019/2020. Penelitian ini merupakan penelitian kuantitatif dengan jenis penelitian eksperimen semu (quasy eksperiment) dan desain Nonequivalent Post-Test Only Control Group Design. Terdapat dua kelompok yang telah dipilih secara cluster random sampling kemudian pelaksanaan kegiatan pembelajaran menggunakan model pembelajaran Make A Match dengan berbantuan media kartu berpasangan. Siyoto \& Sodik (2015) menjelaskan bahwa "populasi adalah wilayah generalisasi yang terdiri atas objek/subjek yang mempunyai kualitas dan karakteristik tertentu yang ditetapkan oleh peneliti untuk dipelajari dan kemudian ditarik kesimpulannya". Populasi dalam penelitian ini adalah seluruh kelas III di Gugus 1 Melinggih, Kecamatan Payangan, Kabupaten Gianyar pada tahun pelajaran 2019/2020 yang berjumlah 92 orang dan terdistribusi ke dalam 5 kelas yaitu kelas III SDN 1 Melinggih, kelas III SDN 2 Melinggih, kelas III SDN 3 Melinggih, kelas III SDN 4 Melinggih, kelas III SDN 5 Melinggih. Penentuan sampel untuk kelompok eksperimen dan kelompok kontrol berdasarkan populasi siswa kelas III SDN Gugus 1 Melinggih, Kecamatan Payangan, Kabupaten Gianyar tahun pelajaran 2019/2020 digunakan teknik cluster random sampling melalui undian secara acak. Sugiyono (2007) menyatakan bahwa, teknik cluster random sampling digunakan untuk menentukan sampel bila obyek yang akan diteliti atau sumber data sangat luas, missal penduduk dari suatu negara, propinsi, atau kabupaten. Untuk menentukan penduduk mana yang akan dijadikan sumber data, maka pengambilan 
sampel ditetapkan secara bertahap dari wilayah yang luas ke wilayah terkecil. Setelah terpilih sampai terkecil, kemudian baru dipilih sampel secara acak. Cara ini digunakan untuk membuka peluang yang sama terhadap keseluruhan populasi agar dapat menjadi anggota sampel yang diinginkan. Variabel dalam penelitian ini yaitu variabel bebas (model Make A Match berbantuan media kartu berpasangan) dan variabel terikat (media kartu berpasangan). Hadi (dalam Arikunto, 2006) menyatakan bahwa, "variabel sebagai gejala yang bervariasi misalnya jenis kelamin, karena jenis kelamin mempunyai variasi: laki-laki perempuan; berat badan, karena ada berat badan $40 \mathrm{~kg}$, dan sebagainya. Gejala adalah objek penelitian, sehingga variabel adalah objek penelitian yang bervariasi.

Sebelum pemilihin secara acak dilakukan, terlebih dahulu dilakukan uji kesetaraan kelas dengan menggunakan Anava A. Data yang digunakan dalam melakukan uji kesetaraan dengan Anava A adalah nilai PTS Matematika siswa kelas III Gugus I Melinggih, Kecamatan Payangan, Gianyar.

Berdasarkan, hasil uji kesetaraan menggunakan Anava A, apabila hasil yang diperoleh pada taraf signifikansi 5\%, jika $\mathrm{F}_{\text {hitung }}<\mathrm{F}_{\text {tabel, }}$ maka $\mathrm{H}_{0}$ diterima dan $\mathrm{H}_{\mathrm{a}}$ ditolak yang berarti tidak terdapat perbedaan yang signifikan (setara). Sedangkan, apabila hasil yang diperoleh pada taraf signifikansi 5\%, jika $\mathrm{F}_{\text {hitung }}>$ $\mathrm{F}_{\text {tabel, }}$, maka $\mathrm{H}_{0}$ ditolak dan $\mathrm{H}_{\mathrm{a}}$ diterima yang berarti terdapat perbedaan yang signifikan (tidak setara). Berdasarkan hasil uji kesetaraan menggunakan Anava A, diperoleh hasil $F_{\text {hitung }}<F_{\text {tabel }}(1,306<2,48)$, dengan $\mathrm{H}_{0}$ diterima dan $\mathrm{H}_{\mathrm{a}}$ ditolak yang berarti tidak terdapat perbedaan yang signifikan hasil Penilaian Tengah Semester siswa kelas III Gugus I Melinggih, Payangan, Gianyar. Setelah diketahui seluruh kelas mempunyai kemampuan yang setara, penentuan sampel dilanjutkan dengan teknik pengundian. Dari hasil pengundian yang telah dilakukan, didapatkan SDN 2 Melinggih sebagai kelas eksperimen dan SDN 4 Melinggih sebagai kelas kontrol. Kelas eksperimen merupakan kelas yang akan mendapatkan perlakuan berupa model pembelajaran make a match dengan berbantuan media kartu berpasangan, dan kelas kontrol merupakan kelas yang tanpa mendapatkan perlakuan berupa model pembelajaran Make A Match dengan berbantuan media kartu berpasangan.

Dalam penelitian ini, instrumen pengumpulan data yang digunakan adalah tes pilihan ganda yang akan dibagikan kepada siswa-siswa yang sudah dipilih sebagai sampel. Tes ini berisi 20 butir pernyataan yang dibuat berdasarkan dimensi kognitif yang meliputi memahami (C2), mengaplikasikan (C3), dan menganalisis (C4). Setiap butir soal akan disertai dengan alternatif jawaban yaitu pilihan a, b, c, atau d. Setiap butir soal dengan jawaban benar akan diberikan skor satu, sedangkan soal yang dijawab salah akan diberikan skor nol. Skor dari jawaban tersebut akan dijumlahkan dan hasil dari penjumlahan tersebut adalah skor hasil belajar matematika siswa. Koyan (2011) menyatakan bahwa kualitas alat ukur hasil belajar pada ranah kognitif ditentukan oleh beberapa faktor yaitu validitas tes, reliabilitas tes, taraf kesukaran tes, dan daya pembeda tes. Uji Validitas terdiri dari uji validitas isi dan uji validitas butir. 1) Candiasa (2011) menjelaskan bahwa validitas isi menyangkut isi dan format instrumen. Dalam tes hasil belajar, validitas isi bisa dicapai dengan membuat kisi-kisi tes, sebelum tes tersebut disusun. Validitas isi dilakukan dengan formula Gregory dengan menggunakan penilaian pakar atau ahli. Berdasarkan penilaian dari kedua pakar didapatkan hasil validitas yaitu 1,00, yang menunjukkan bahwa validitas isi instrumen hasil belajar matematika "sangat tinggi". 2) Validitas butir yang diujicobakan dapat ditentukan dengan koefisien korelasi product moment. Berdasarkan hasil analisis hasil belajar matematika dengan berbantuan program Microsoft Excel, diperoleh harga " $r$ " tabel sebesar 0,228 (pada taraf signifikansi 5\%). Tes dikatakan valid jika $r_{x y}>r_{\text {tabel. }}$. Sebaliknya, tes dikatakan tidak valid jika $r_{x y}<r_{\text {tabel }}$. Dari hasil pengujian validitas butir, keseluruhan nilai $r_{x y}>r_{\text {tabel, }}$, sehingga 20 butir soal yang diujicobakan terbukti valid. Setelah melewati pengujian validitas, selanjutnya dilakukan pengujian reliabilitas butir soal hasil belajar matematika menggunakan rumus Kuder-Richadson 20 (KR-20). Koyan (2011) menyatakan bahwa reliabilitas alat ukur adalah keajegan alat ukur, yang berarti kapanpun alat ukur itu digunakan akan menghasilkan hasil ukur yang relative tetap. Berdasarkan hasil perhitungan nilai koefisien realibilitas $\left(\mathrm{r}_{1.1}\right)$ dengan berbantuan program Microsoft Excel, untuk 20 butir soal yang valid, koefisien reliabilitas sebesar 0,79 dengan kategori "sangat tinggi". Setelah itu, dilakukan pengujian tingkat kesukaran 20 butir soal. Tingkat kesukaran butir tes merupakan bilangan yang menunjukkan proporsi peserta ujian (testee) yang dapat menjawab benar butir soal tersebut (Koyan, 2011). Berdasarkan hasil perhitungan dengan berbantuan program Microsoft Excel, diperoleh 12 butir soal pada kategori mudah, 7 butir soal pada kategori sedang, dan 1 butir soal pada kategori sukar. Selanjutnya, dilakukan pengujian terhadap daya beda tes. Berdasarkan hasil perhitungan dengan berbantuan program Microsoft Excel, diperoleh analisis dari daya beda jika dilihat secara keseluruhan memiliki rata-rata daya beda sebesar 0,35 yang berarti berada pada tingkat cukup baik.

Setelah itu, kemampuan siswa pada kelompok eksperimen dan kelompok kontrol akan diuji menggunakan tes pilihan ganda tersebut. Kemudian, hasil dari post test tersebut akan dianalisis dengan analisis statistik deskripstif dan uji prasyarat analisis data. Agung (2014:110) menyatakan bahwa analisis statistik deskriptif adalah cara pengolahan suatu data menggunakan rumus-rumus untuk 
menggambarkan suatu objek atau variabel tertentu, sehingga diperoleh kesimpulan umum.Analisis statistik deskriptif terdiri dari menghitung rata-rata (mean), menghitung median, menghitung modus, dan menghitung standar deviasi. Uji prasyarat analisis data terdiri dari uji normalitas dan uji homogenitas. Setelah data memenuhi uji persyaratan maka dilanjutkan dengan melakukan uji hipotesis. Dalam menentukan penggunaan rumus uji t menurut Sugiyono (dalam Koyan, 2012), adalah sebagai berikut.

1) Jika anggota sampel $n_{1}=n_{2}$ dan varians homogen, maka dapat digunakan rumus t-test, baik untuk sparated maupun polled varians, $\mathrm{db}\left(\mathrm{n}_{1}+\mathrm{n}_{2}\right)-2$

2) Jika $n_{1} \neq n_{2}$, varians homogen dapat digunakan t-test dengan polled varians, dengan derajat kebebasan $\left(\mathrm{n}_{1}+\mathrm{n}_{2}\right)-2$

3) Jika $n_{1}=n_{2}$ dan tidak homogen, dapat digunakan salah satu rumus di atas, dengan $d b=n_{1}-1$ atau $n_{2}-$ 1 (bukan $\mathrm{n}_{1}+\mathrm{n}_{2}-2$ ).

4) Jika $\mathrm{n}_{1} \neq \mathrm{n}_{2}$ dan tidak homogen, digunakan rumus sparated varians, harga $\mathrm{t}$ pengganti $\mathrm{t}$ tabel dihitung selisih dari harga $t$ table dengan $d b=\left(n_{1}-1\right)$ dan $d b=\left(n_{2}-1\right)$, dibagi dua, kemudian ditambah dengan dengan harga t yang terkecil.

Kriteria untuk pengujian hipotesis adalah $\mathrm{H}_{0}$ diterima jika $\mathrm{t}_{\text {hitung }}<\mathrm{t}_{\text {tabel }}$ dan $\mathrm{H}_{0}$ ditolak jika $\mathrm{t}_{\text {hitung }}>$ $t_{\text {tabel. }}$ Pengujian ini dilakukan pada taraf signifikan 5\%. Jadi dapat disimpulkan sebagai berikut.

$\mathrm{H}_{0}$ : Tidak terdapat pengaruh yang signifikan model pembelajaran Make A Match dengan berbantuan media Kartu Berpasangan terhadap hasil belajar matematika siswa kelas III Gugus I Melinggih Kecamatan Payangan, Kabupaten Gianyar Tahun Pelajaran 2019/2020

$\mathrm{H}_{\mathrm{a}}$ : Terdapat pengaruh yang signifikan model pembelajaran Make A Match dengan berbantuan media Kartu Berpasangan terhadap hasil belajar matematika siswa kelas III Gugus I Melinggih Kecamatan Payangan, Kabupaten Gianyar Tahun Pelajaran 2019/2020.

\section{ANALISIS DAN PEMBAHASAN}

Data yang dianalisis dalam penelitian ini adalah data hasil belajar Matematika siswa kelas III Tema 7 Perkembangan Teknologi. Data hasil belajar Matematika diperoleh dari hasil post-test yang diberikan pada akhir penelitian. Kelompok eksperimen pada penelitian ini adalah siswa kelas III SDN 2 Melinggih dan kelas kontrol pada penelitian ini adalah siswa kelas III SDN 4 Melinggih. Instrumen pengumpulan data yang digunakan dalam penelitian ini adalah instrumen test berupa soal pilihan ganda yang berjumlah 20 butir soal. Desain penelitian yang digunakan dalam penelitian ini adalah Nonequivalent Control Group Design yang menggunakan uji-t dengan rumus polled varians untuk pengujian hipotesisnya.

Penelitian ini dilaksanakan dengan tujuan untuk mengetahui pengaruh model pembelajaran Make A Match dengan berbantuan media Kartu Berpasangan terhadap hasil belajar matematika siswa kelas III Gugus I Melinggih Kecamatan Payangan, Kabupaten Gianyar Tahun Pelajaran 2019/2020. Data dalam penelitian ini adalah skor hasil belajar matematika siswa sebagai akibat dari penerapan model pembelajaran Make A Match dengan berbantuan media Kartu Berpasangan pada kelompok eksperimen dan bukan model pembelajaran Make A Match dengan berbantuan media Kartu Berpasangan pada kelompok kontrol.

Berdasarkan deskripsi data, kelompok siswa yang mengikuti pembelajaran dengan model Make A Match berbantuan media kartu berpasangan memiliki skor hasil belajar yang lebih tinggi (kelompok eksperimen) dibandingkan dengan kelompok siswa yang mengikuti pembelajaran dengan bukan model pembelajaran Make A Match berbantuan media kartu berpasangan (kelompok kontrol). Perbedaan yang signifikan antara kelompok eksperimen dan kelompok kontrol ini disebabkan oleh perbedaan perlakuan yang diberikan pada masing-masing kelompok tersebut. Pada kelompok eksperimen, pembelajaran menggunakan model Make A Match berbantuan media kartu berpasangan, sedangkan pada kelompok kontrol, pembelajaran menggunakan bukan model Make A Match berbantuan media kartu berpasangan. Jadi, letak perbedaan antara kelompok eksperimen dan kelompok kontrol adalah cara penyampaian materi pembelajaran dengan langkah-langkah pembelajaran yang berbeda. Pada penelitian ini, rata-rata skor hasil belajar siswa yang diperoleh pada kelompok eksperimen lebih besar daripada kelompok kontrol. Pada kelompok eksperimen hasil belajar matematika siswa kelas III Gugus I Melinggih yang diajarkan dengan menggunakan model pembelajaran Make A Match berbantuan media kartu berpasangan memperoleh nilai post-test dengan jumlah siswa sebanyak 23 siswa, skor maksimum $=19$, skor minimum $=10$, mean $=15,98$, median $=16,36$, modus $=17,1$, dan standar deviasi $=6,31$. Pada kelompok kontrol, hasil belajar matematika siswa kelas III Gugus I Melinggih yang diajarkan dengan menggunakan bukan model pembelajaran Make A Match berbantuan media kartu berpasangan memperoleh nilai post-test dengan jumlah siswa sebanyak 24 siswa, skor maksimum $=19$, skor minimum $=6$, mean $=13$, median $=$ 12,79 , modus $=11,11$, dan standar deviasi $=11,39$. Untuk lebih jelasnya disajikan dalam tabel 1. 
Tabel 1. Rekapitulasi Hasil Perhitungan Statistik Deskritif Post-test Skor Hasil Belajar Matematika Kelompok Eksperimen dan Kontrol

\begin{tabular}{cccc}
\hline No. & Statistik Deskritif & Eksperimen & Post-test \\
\hline 1 & Banyak Siswa & 23 & Kontrol \\
2 & Skor Maksimum & 19 & 24 \\
3 & Skor Minimum & 10 & 19 \\
4 & Mean & 16,1 & 6 \\
5 & Median & 16,36 & 13 \\
6 & Modus & 17,1 & 12,79 \\
7 & Standar Deviasi & 2,5 & 11,11 \\
8 & Varians & 6,25 & 3,31 \\
\hline
\end{tabular}

Berdasarkan Tabel 1, untuk menentukan kualitas variabel-variabel di atas, skor rata-rata (mean) tiap-tiap variabel dikonversikan dengan menggunakan kriteria rata-rata ideal dan Standar deviasi (SD). Untuk mempermudah dalam menghitung rata-rata ideal dan standar deviasi ideal dapat dibuat skala penelitian yang ditunjukkan pada.

Tabel 2. Skala Penilaian pada Skala Lima

\begin{tabular}{ccc}
\hline Rentang Skor & Rentang Skor & Kategori \\
\hline $\mathrm{Mi}+1,5 \mathrm{SDi} \leq X \leq \mathrm{Mi}+3,0 \mathrm{SDi}$ & $14,995 \leq \mathrm{X} \leq 20$ & Sangat tinggi \\
$\mathrm{Mi}+0,5 \mathrm{SDi} \leq X<\mathrm{Mi}+1,5 \mathrm{SDi}$ & $11,665 \leq \mathrm{X} \leq 14,995$ & Tinggi \\
$\mathrm{Mi}-0,5 \mathrm{SDi} \leq X<\mathrm{Mi}+0,5 \mathrm{SDi}$ & $8,335 \leq \mathrm{X} \leq 11,665$ & Sedang \\
$\mathrm{Mi}-1,5 \mathrm{SDi} \leq X<\mathrm{Mi}-0,5 \mathrm{SDi}$ & $5,005 \leq \mathrm{X} \leq 8,335$ & Rendah \\
$\mathrm{Mi}-3,0 \mathrm{SDi} \leq X<\mathrm{Mi}-1,5 \mathrm{SDi}$ & $0,00 \leq \mathrm{X} \leq 5,005$ & Sangat rendah \\
\hline
\end{tabular}

(sumber: dimodifikasi dari Koyan, 2012)

Sebelum dilakukan uji hipotesis menggunakan metode statistik dengan uji-t, terlebih dahulu data melalui pengujian asumsi yang meliputi uji normalitas sebaran data, dan uji homogenitas varian.

Uji normalitas dilakukan dengan menggunakan bantuan SPSS pada uji kolmogrov-Smirnov dan Shapiro-Wilk. Kriteria pengujian adalah data berdistribusi normal jika angka signifikansi (sig.) $>0,05$. Rangkuman hasil uji normalitas data hasil belajar Matematika siswa dapat dilihat pada Tabel 3.

Tabel 3. Hasil Uji Normalitas Hasil Belajar Matematika

\begin{tabular}{|c|c|c|c|c|c|c|c|}
\hline \multicolumn{8}{|c|}{ Tests of Normality } \\
\hline & Kelas & Kolmo & $\mathrm{v}-\mathrm{Sr}$ & & Sh & $0-W$ & \\
\hline \multirow{3}{*}{ Hasil Belajar } & & Statistic & Df & Sig. & Statistic & Df & Sig. \\
\hline & Kelas Ekperimen & .159 & 23 & .136 & .926 & 23 & .091 \\
\hline & Kelas Kontrol & .102 & 23 & .200 & .969 & 23 & .658 \\
\hline
\end{tabular}

Berdasarkan Tabel 3, untuk uji Kolmogorov-Smirnov nilai signifikansi hasil belajar Matematika siswa pada kelas eksperimen 0,136 > 0,05 sedangkan kelas kontrol 0,200>0,05 yang berarti data hasil belajar Matematika siswa yang diuji dengan menggunakan uji Kolmogorov-Smirnov berdistribusi normal. Uji Shapiro-Wilk nilai signifikansi hasil belajar Matematika pada kelas eksperimen 0,091 > 0,05 sedangkan kelas kontrol 0,658 > 0,05 yang berarti hasil belajar Matematika siswa yang diuji dengan menggunakan uji Shapiro-Wilk berdistribusi normal. Sehingga dapat disimpulkan data hasil belajar Matematika siswa pada kelas eksperimen maupun kelas kontrol berdistribusi normal.

Uji homogenitas varians dalam penelitian ini menggunakan bantuan SPSS. Data dikatakan memiliki varians yang homogen jika signifikansinya lebih dari 0,05 dan data dikatakan tidak homogen jika signifikansinya kurang dari 0,05. Rangkuman hasil homogenitas varian untuk hasil belajar matematika siswa pada kelas eksperimen dan kelas kontrol disajikan pada Tabel 4. 
Tabel 4. Hasil Uji Homogenitas Kelompok Eksperimen dan Kontrol

\begin{tabular}{ccccc}
\hline \multicolumn{5}{c}{ Test of Homogeneity of Variance } \\
\hline \multirow{2}{*}{ Hasil Belajar } & $\mathrm{F}$ & $\mathrm{df1}$ & $\mathrm{df2}$ & Sig. \\
& 2.865 & 1 & 45 & .097 \\
\hline
\end{tabular}

Berdasarkan Tabel 4, nilai signifikansi hasil belajar matematika siswa yaitu 0,97 > 0,05 yang berarti, data hasil belajar matematika siswa pada kelas eksperimen dan kelas kontrol memiliki varians yang homogen. Berdasarkan hasil dari uji prasyarat analisis yang meliputi uji normalitas dan uji homogenitas varian, diperoleh hasil bahwa data kelompok eksperimen dan kelompok kontrol berdistribusi normal dan memiliki varian homogen. Setelah melakukan uji prasyarat analisis data, kemudian dilanjutkan dengan pengujian hipotesis. Pengujian hipotesis penelitian dengan uji-t dengan menggunakan bantuan rumus polled varians. Kriteria untuk pengujian hipotesis adalah $\mathrm{H}_{0}$ diterima jika $t_{\text {hitung }}<t_{\text {tabel }}$ dan $\mathrm{H}_{0}$ ditolak jika $t_{\text {hitung }}>t_{\text {tabel. }}$. Pengujian ini dilakukan pada taraf signifikan 5\%. Data hasil pengujian hipotesis dengan uji-t, nilai $t_{\text {hitung }}$ adalah 3,42 , dan $t_{\text {tabel }}$ dengan taraf signifikan $5 \%$ dan $d b=$

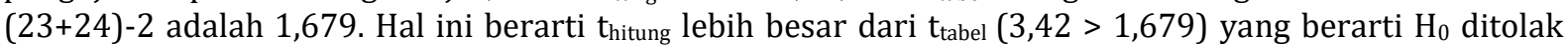
dan $\mathrm{H}_{\mathrm{a}}$ diterima. Sehingga dapat disimpulkam bahwa terdapat pengaruh model pembelajaran Make $A$ Match berbantuan media kartu berpasangan terhadap hasil belajar matematika siswa kelas III Gugus I Melinggih Kecamatan Payangan, Kabupaten Gianyar Tahun Pelajaran 2019/2020.

\section{KESIMPULAN}

Dari hasil penelitian dan analisis data tentang pengaruh model pembelajaran Make A Match berbantuan media kartu berpasangan terhadap hasil belajar matematika siswa kelas III Gugus I Melinggih Kecamatan Payangan, Kabupaten Gianyar Tahun Pelajaran 2019/2020, maka dapat disimpulkan bahwa, hasil belajar matematika siswa kelas III Gugus I Melinggih yang diajarkan dengan menggunakan model pembelajaran Make A Match berbantuan media kartu berpasangan memperoleh nilai post-test dengan jumlah siswa sebanyak 23 siswa, skor maksimum $=19$, skor minimum $=10$, mean $=15,98$, median $=$ 16,36 , modus $=17,1$, dan standar deviasi $=6,31$ dan hasil belajar matematika siswa kelas III Gugus I Melinggih yang diajarkan dengan menggunakan bukan model pembelajaran Make A Match berbantuan media kartu berpasangan memperoleh nilai post-test dengan jumlah siswa sebanyak 24 siswa, skor maksimum $=19$, skor minimum $=6$, mean $=13$, median $=12,79$, modus $=11,11$, dan standar deviasi $=$ 11,39. Berdasarkan hasil perhitungan uji hipotesis, nilai $t_{\text {hitung }}$ adalah 3,42 , dan $t_{\text {tabel }}$ dengan taraf signifikan $5 \%$ dan $d b=(23+24)-2$ adalah 1,679. Hal ini berarti $t_{\text {hitung }}$ lebih besar dari $t_{\text {tabel }}(3,42>1,679)$ yang berarti $\mathrm{H}_{0}$ ditolak dan $\mathrm{H}_{\mathrm{a}}$ diterima. Sehingga dapat disimpulkam bahwa terdapat pengaruh model pembelajaran Make A Match berbantuan media kartu berpasangan terhadap hasil belajar matematika siswa kelas III Gugus I Melinggih Kecamatan Payangan, Kabupaten Gianyar Tahun Pelajaran 2019/2020.

Saran-saran yang dapat disampaikan berdasarkan hasil penelitian yang telah dilaksanakan adalah sebagai berikut. (1) Kepada siswa disarankan agar belajar lebih giat lagi dan selalu memotivasi diri agar semangat dalam belajar untuk bekal masa depan yang lebih baik, (2) Kepada guru agar menerapkan berbagai jenis model pembelajaran yang cocok sesuai dengan materi pembelajaran guna mempermudah proses penyampaian materi dan mempermudah pemahaman antara guru dan siswa, (3) Kepada kepala sekolah agar membina guru-guru dalam melaksanakan proses pembelajaran yang berkualitas, (4) Kepada peneliti bidang sejenis agar hasil penelitian ini dapat dijadikan referensi maupun acuan untuk melaksanakan penelitian penelitian sejenis tanpa adanya unsur plagiarisme.

\section{DAFTAR PUSTAKA}

Abadi. 2012. Statistik Pendidikan Teknik Analisis Data Kuantitatif. Singaraja: Undiksha Press

Abadi, Darsana, \& Ningsih. 2018. Korelasi Antara Minat Belajar dengan Hasil Belajar IPS. Mimbar PGSD Undiksha. Vol: 6 No: 3 Tahun: 2018

Agung, Anak Agung Gede. 2014. Metodologi Penelitian Pendidikan. Malang: Aditya Media Publishing

Andri, Septia, \& Yunita. 2016. Pengaruh Penerapan Model Pembelajaran Problem Based Learning Disertai Teknik Kepala Bernomor Terhadap Hasil Belajar Matematika Siswa SMP Kelas VIII. Jurnal Pelangi. Vol. 9 No.1 Desember 2016 Halaman 19-23 
Arifiyanti, Umi Hani. 2016. Penerapan Model Pembelajaran Kooperatif Tipe Make A Match Dengan Menggunakan Media Kartu Untuk Meningkatkan Hasil Belajar Siswa Kelas XI IPS 4 SMA Negeri 1 Mojolaban Tahun Ajaran 2015/2016. Jurnal Penelitian

Arikunto, Suharsimi. 2006. Prosedur Penelitian Suatu Pendekatan Praktik. Jakarta: PT Rineka Cipta

Candiasa, I Made. 2011. Pengujian Instrumen Penelitian Disertai Aplikasi ITEMAN dan BIGSTEPS. Singaraja: Undiksha Press

Dari, Anak Agung Indah Wisma. 2016. Pengaruh Pendekatan Konvensional Berbasis Model Pembelajaran Kooperatif Tipe Make A Match Terhadap Kompetensi Pengetahuan PKn Siswa Kelas V SD Gugus Letkol Wisnu Tahun Pelajaran 2015/2016. Skripsi: Universitas Pendidikan Ganesha

Dewi, Ni Made Ria Rosita. 2017. Pengaruh Model Pembelajaran Make A Match Berbatuan Media Konkrit Terhadap Hasil Belajar IPA Siswa Kelas V SD Gugus III Kecamatan Jembrana Kabupaten Jembrana Tahun Pelajaran 2016/2017. Skripsi: Universitas Pendidikan Ganesha

Gandhi, Teguh Wangsa. 2011. Filsafat Pendidikan. Jogjakarta: AR-Ruzz Media

Haji, Sun. 2015. Pembelajaran Tematik Yang Ideal Di SD/MI. Jurnal Vol. III, No. 1, Maret 2015

Harsa, Fajar Sukma. 2017. Analisis Keterampilan Mengajar Guru Terhadap Pembelajaran Matematika Di Kelas X Smk. Jurnal Pelangi. Vol. 9 No.2 Juni 2017 Halaman 79-87

Hutauruk \& Simbolon. 2018. Meningkatkan Hasil Belajar Siswa Dengan Alat Peraga Pada Mata Pelajaran IPA Kelas IV SDN Nomor 14 Simbolon Purba. School Education Journal. Vol. 8. No 2 Juni 2018

Koyan, I Wayan. 2011. Asesmen dalam Pendidikan. Singaraja: Undiksha Press

Mulyatiningsih, Endang. 2011. Metode Penelitian Terapan Bidang Pendidikan. Bandung: Alfabeta

Novayanti, Dewi. 2017. Pengembangan Media Card Match (Kartu Berpasang) Pada Materi APBN dan APBD Kelas XI IIS SMAN 1 Krembung. Jurnal Pendidikan Ekonomi. Volume 05 Nomor 03 (2017).

Nugraha, Susanti, \& Masykuri. 2013. Efektivitas Metode Pembelajaran Kooperatif Think Pair Share (Tps) Yang Dilengkapi Media Kartu Berpasangan (Index Card Match) Terhadap Prestasi Belajar Siswa Pada Materi Ikatan Kimia Kelas X Semester Gasal Sma N 2 Karanganyar Tahun Pelajaran 2012/2013. Jurnal Pendidikan Kimia (Jpk). Vol. 2 No. 4 Tahun 2013

Nurdyasyah \& Fahyuni. 2016. Inovasi Model Pembelajaran. Sidoarjo: Nizamia Learning Center.

Pertiwi, Sumarno, \& Dwi. 2019. Pengaruh Model Make A Match Berbantuan Media Kartu Bergambar terhadap Kemampuan Membaca dan Menulis. Mimbar PGSD Undiksha. Vol: 7 No: 3 Tahun: 2019

Pratiwi, Noor Komari. 2015. Pengaruh Tingkat Pendidikan, Perhatian Orang Tua, dan Minat Belajar Siswa Terhadap Prestasi Belajar Bahasa Indonesia Siswa SMK Kesehatan di Kota Tangerang. Jurnal Pujangga. Volume 1, Nomor 2, Desember 2015

Rifai, Agus. 2010. Media Teknologi. Tanggerang Selatan: Universitas Terbuka

Siyoto \& Sodik. 2015. Dasar Metodologi Pendidikan. Yogyakarta: Literasi Media Publishing

Sugiyono. 2007. Statistika untuk Penelitian. Bandung: CV Alfabeta

Suranata, Suarjana, \& Prasetya. 2018. Pengaruh Model Pembelajaran Self Regulated Learning (SRL) Berbantuan LKS Terhadap Prestasi Belajar Matematika. Mimbar PGSD Undiksha Vol: 6 No: 3 Tahun: 2018 
Susanty, Nurkamto, \& Suharno. 2014. Pengaruh Pembelajaran Cooperatif Tipe Make A Match dan Pembelajaran Konvensional Terhadap Hasil Belajar PKn Ditinjau Dari Kemandirian Belajar Siswa Pada MTS N Di Kabupaten Kudus. Jurnal Teknologi Pendidikan dan Pembelajaran. Vol.2, No.2, Hal 257-272, Edisi April 2014

Sutrisno, Valiant Lukad Perdana. 2016. Faktor-Faktor yang Mempengaruhi Hasil Belajar Siswa Pada Pembelajaran Praktik Kelistrikan Otomotif SMK di Kota Yogyakarta. Jurnal Pendidikan Vokasi. Volume 6, No 1, Februari 2016 (111-120)

Tarigan, Daitin. 2014. Meningkatkan Aktivitas Belajar Siswa Dengan Menggunakan Model Make A Match Pada Mata Pelajaran Matematika di Kelas V SDN 050687 Sawit Seberang. Jurnal Kreano. Volume 5 Nomor 1 Bulan Juni Tahun 2014

Tiballa. Meida Dwi Sana. 2017. Pengaruh Model Pembelajaran Kooperatif Tipe Make A Match Berbatuan Peta Pikiran Terhadap Hasil Belajar IPA Siswa Kelas V Sekolah Dasar Gugus X Kecamatan Buleleng Kabupaten Buleleng Tahun Pelajaran 2016/2017. Skripsi: Universitas Pendidikan Ganesha

Yulianti \& Yuniasih. 2016. Telaah Kurikulum dan Aplikasinya dalam Proses Belajar Mengajar. Malang: CV Media Sutra Atiga

Zahroul \& Nur. 2014. Model Pembelajaran Kooperatif Teknik Make A Match Sebagai Upaya Peningkatan Aktivitas dan Hasil Belajar Siswa Kelas IV SD Dalam Pembelajaran IPS Pokok Bahasan Perkembangan Teknologi Produksi, Komunikasi Dan Transportasi. Jurnal Pedagogi. Volume 1 Nomor 1, Agustus 2014 